\title{
DEMOKRASI DAN DEMOKRATISASI: SEBUAH KERANGKA KONSEPTUAL UNTUK MEMAHAMI DINAMIKA SOSIAL-POLITIK DI INDONESIA
}

Oleh:

\section{Heru Nugroho}

\begin{abstract}
Abstrak
Keruntuhan komunisme pada tahun 1989 menjadi momentum yang krusial bagi demokrasi sebagai sebuah sistem politik untuk menyebarkan pengaruhnya ke seluruh penjuru dunia. Sebagai sebuah konsep, demokrasi mempunyai makna yang luas dan juga kompleksitasnya sendiri. Artikel ini ingin menjelaskan varian dari demokrasi terutama debat antara demokrasi liberal dengan demokrasi sosial. Selain itu, penulis juga menjelaskan praktek demokrasi di Indonesia setelah era reformasi 1998 dan menunjukkan masalah yang dihadapi oleh negara ini dalam menciptakan masyarakat yang demokratis. Sebagai kesimpulan, artikel ini ingin menjelaskan bahwa demokratisasi di Indonesia masih dalam proses dan masih banyak hal yang perlu dibenahi.
\end{abstract}

Kata kunci: demokratisasi, liberal, sosial, akselerasi, Indonesia

\begin{abstract}
The collapse of communism in 1989 became an important moment for democracry as a political system to spread its influences all over the world. As a concept, democracy has wide meanings and its complexities. This article wants to explain the variant of democracy especially the debate between liberal democracy and social democracy. I would also like to explain the practice of democracy in Indonesia after reformation 1998 and showing the problem that faced by this country to create democratic society. In conclusion, this article wants to tell that the democratization in Indonesia is still in process and there are lots of things that needs to be fixed.
\end{abstract}

Keywords: democratization, liberal, social, acceleration, Indonesia. 


\section{A. Pendahuluan}

Istilah demokrasi pada dua dasawarsa terakhir, khususnya di berbagai negara berkembang kian populer, baik pada tingkat wacana maupun aras gerakan sosial politik. Sebagai suatu sistem politik, demokrasi telah menempati stratum teratas yang diterima oleh banyak negara karena dianggap mampu mengatur dan menyelesaikan hubungan sosial dan politik, baik yang melibatkan kepentingan antar individu dalam masyarakat, hubungan antar masyarakat, masyarakat dan negara maupun antar negara di dunia. Ambruknya ideologi komunisme Uni Soviet tahun 1989, setidaknya telah menjadi momentum penting bagi perluasan demokrasi sebagai wacana pilihan sistem politik. Kepopuleran demokrasi sebagai ideologi politik secaracepat

menyebar oleh berkembangnya wacana kritis yang sebagian besar mengungkapkan kegagalan praktek otoritarianisme. Hadirnya demokrasi seakan telah menjadi hal berarti dan nyata mengatasi masalah sosial politik yang selama ini diderita berbagai negara.

Sebagai sebuah konsep, demokrasi memiliki makna luas dan mengandung banyak elemen yang kompleks. Demokrasi adalah suatu metode politik, sebuah mekanisme untuk memilih pemimpin politik. Warga negara diberi kesempatan untuk memilih salah satu diantara pemimpin-pemimpin politik yang bersaing meraih suara (David Lechmann, 1989). Kemampuan untuk memilih diantara pemimpin-pemimpin politik pada masa pemilihan inilah yang disebut demokrasi. Jadi dengan kata lain dapat diungkap bahwa demokrasi adalah suatu metode penataan kelembagaan untuk sampai pada keputusan politik, dimana individu meraih kekuasaan untuk mengambil keputusan melalui perjuangan kompetitif dalam meraih suara. Namun demikian, proses kompetisi itu harus tetap dibingkai oleh etika normatif yang mengarah pada terjadinya equlibrium sosial.

Dalam demokrasi kesantunan politik harus tetap dijaga. Konsep liberalisasi yang melekat pada ideologi demokrasi musti diartikan sebagai sebuah masyarakat yang bebas dan bertanggung jawab, yaitu masyarakat yang memiliki aturan main yang jelas sehingga si kuat tidak menindas si lemah. Ini dapat terjadi kalau ada hukum yang mengatur segala bentuk permainan, baik politik, ekonomi, dan kebudayaan. Aturan main itu hendaknya menjamin pemberian ruang gerak atau kesempatan yang sama bagi setiap warga negara untuk melakukan aktifitas kehidupannya. Aturan main yang sudah dirumuskan dan dituangkan dalam bentuk hukum tersebut seyogyanya dihormati oleh setiap aktor sosial dalam segala tingkat dan kapasitas. Dengan kata lain, baik itu penguasa, pemerintah, pengusaha dan rakyat kebanyakan semuanya harus hormat dan tunduk pada hukum (aturan main). Barang siapa yang menyimpang dari aturan main atau barang siapa yang mencoba memanipulasi aturan main dapat ditindak melalui lembaga peradilan tanpa pandang bulu.

Kalau kesadaran akan logika demokasi seperti itu sudah melembaga dan diinternalilasi oleh individu setiap anggota masyarakat, maka liberalisme 
Jurnal Pemikiran Sosiologi Volume 1 No. 1, 2012

Heru Nugroho

Demokrasi dan Demokratisasi:

Sebuah Kerangka Konseptual untuk Memahami Dinamika Sosial Politik di Indonesia

sebagai "roh demokrasi" justru akan mendatangkan harmoni dan kemajuan peradaban. Kebebasan berusaha (free enterprise), kebebasan bersaing (free fight), kebebasan bersuara dan kebebasan memilih afiliasi politik justru tidak akan mendatangkan kekacauan tetapi kesejahteraan sosial. Tetapi perlu digaris bawahi bahwa kemajuan masyarakat terjadi kalau semua aktor sosial sadar akan aturan main tersebut. Seandainya salah satu pihak melanggar aturan main dalam praktekpolitik khususnya penunjang kekuasaan maka konsep liberalisme akan tereduksi dalam faham Darwinisme (Mangunwijaya,1994). Dalam faham Darwinisme tersebut konsep liberalisme dimaknai sebagai kebebasan yang tanpa batas, barang siapa yang kuat maka dialah yang akan eksis atau "survival of the fittest". Dalam faham ini orang boleh ngomong semaunya sendiri, partai boleh melakukan demagogi hingga kapasitas maksimum, kekuatan politik boleh bertindak apa saja. Sehingga yang muncul bukan equilibrium sosial tapi kondisi yang chaos. Dalam konteks masyarakat yang sedang membangun dan memberdayakan rakyatnya bukan konsep liberalisme dalam pengertian Darwin ini yang perlu di introdusir, namun pengertian liberalisme dalam bingkai kesantunan dan kemaslahatan yang harus diadopsi dan dipelajari.

Dengan suasana liberalisasi yang kondusif ini maka negara akan dapat menjalankan ideologi demokrasinya secara lebih tertata dan konstruktif. Negara demokrasi ini akan dapat mengambil keputusan-keputusan dasar pemerintahannya yang tergantung sepenuhnya pada persetujuan bebas dari yang diperintah. Keterbukaan akan kritik juga merupakan syarat dari negara tipe ini, sehingga aspirasi masyarakat lapis bawah dapat mencuat ke permukaan dan digunakan sebagai landasan kebijakan pemerintah demi kemakmuran nasional. Institusi politik yang liberal merupakan syarat mutlak dari negara yang menyebut dirinya sebagai negara demokratis. Liberalisasi atau demokratisasi merupakan dua hal yang secara total hidup dan berkembang di masyarakat. Demokrasi tidak dapat berjalan in vacuum, maksudnya demokrasi tidak dapat terjadi hanya pada sektor kehidupan politik saja, sementara sektor-sektor kehidupan lainnya tidak demokratis. Atau liberalisasi tidak dapat hanya berlaku dalam bidang ekonomi saja, sementara bidang politik tidak mengalami liberalisasi (David Held, 1987).

Jadi dalam ideologi demokrasi responsifitas pemerintah terhadap preferensi warga negaranya yang setara secara politis harus menjadi dasar pijakannya, oleh karena itu maka negara memiliki kewajiban dalam memberikan peluang dan kesempatan bagi warganya untuk: (1) Merumuskan preferensinya, (2) Menunjukkan preferensi- nya pada warga negara dan pemerintah melalui tindakan pribadi dan kolektif dan (3) memberikan bobot yang sama pada preferensinya, yang dilakukan oleh warga negara (MacPherson. C.B., 1997). Ketiga kesempatan yang harus dimiliki oleh semua warga negara di atas, akan dapat berjalan secara optimal apabila ada sejumlah jaminan kelembagaan. Jaminan itu diantaranya adalah: (1) kebebasan untuk membentuk dan menjadi anggota organisasi, (2) kebebasan mengeluarkan pendapat, (3) hak memilih, (4) kesempatan menjadi pejabat pemerintah, (5) hak bagi pemimpin politik untuk bersaing dalam mencari dukungan, (6) hak bagi 
Jurnal Pemikiran Sosiologi Volume 1 No. 1, 2012

Heru Nugroho

Demokrasi dan Demokratisasi:

Sebuah Kerangka Konseptual untuk Memahami Dinamika Sosial Politik di Indonesia

pemimpin politik untuk bersaing dalam meraih suara, (7) sumber-sumber informasi alternatif, (8) lembaga yang membuat kebijakan pemerintah tergantung kepada perolehan suara dan pengungkapan preferensi lainnya (George Sorensen, 2003). Kedelapan kondisi itu adalah merupakan elemen dasar bagi berlangsungnya iklim demokrasi yang sehat. Secara singkat kedelapan elemen dasar demokrasi itu dapat diringkas dalam tiga dimensi yaitu kompetisi, partisipasi dan kebebasan politik.

Ketika demokrasi diartikan sebagai kompetisi, partisipasi dan kebebasan maka proses demokratisasi (perubahan sistem politik dari bentuk non demokratis ke bentuk yang lebih demokratis), dapat dilakukan dengan dua jalan yang paling esensial yaitu jalan yang terfokus pada kompetisi dan jalan yang terfokus pada partisipasi.

Meningkatnya partisipasi (atau inklusifitas) berarti meningkatnya jumlah warga negara yang memperoleh hak-hak politik dan kebebasan. Rezim non-demokratis mungkin saja menjauhkan sebagian besar masyarakatnya dari partisipasi. Pada rezim demokratis, seluruh penduduk dewasa memperoleh hak kebebasan secara penuh. Kompetisi (atau liberalisasi) menyangkut tersedianya hak-hak dan kebebasan, paling tidak bagi beberapa anggota sistem politik. Meningkatnya liberalisasi berarti meningkatnya peluang bagi oposisi politik dan meningkatnya kompetisi untuk meraih kekuasaan pemerintahan.

Dengan adanya tiga dimensi demokrasi yaitu kompetisi, partisipasi dan kebebasan di suatu negara maka akan lebih membuka peluang bagi berseminya proses demokratisasi. Terciptanya iklim demokratis yang optimal akan berdampak pada semakin menguatnya hak-hak warga negara dalam mengekspresikan aspirasinya. Hak-hak warga yang harus diperjuangkan dan diakomodasi dalam sistem politik yang demokratis adalah: (1) perjuangan untuk mendapatkan otoritas bagi parlemen terpilih untuk mengambil keputusan/kebijakan, perjuangan untuk memperoleh perluasan atas hak memilih, (3) perjuangan untuk membuat subyek penguasa berhubungan dengan kehendak para pemilih, (4) perjuangan untuk mengadakan pemilu berdasarkan perhitungan yang jujur, (5) perjuangan bagi diterimanya partai-partai politik yang terorganisir sebagai aktor sosial yang memiliki legitimasi dan sebagai peserta pemilu, (6) perjuangan bagi terciptanya emansipasi bagi sekelompok masyarakat yang secara personal masih bergantung pada kelompok dominan agar mereka juga memiliki hak memilih pemerintah mereka. Apabila suatu negara dapat menegakkan pilar demokrasi secara stabil dan kuat, maka bukan suatu hal yang mustahil bagi negara itu untuk merealisasikan kondisi yang menjadi parameter berlangsungnya sistem politik yang bercorak poliarki. Adapun parameter yang harus dimiliki pemerintahan yang bersifat poliarki adalah: (1) para pemimpinnya tidak menggunakan koersi kekerasan, yaitu polisi dan militer untuk meraih atau mempertahankan kekuasaannya, (2) adanya organisasi masyarakat pluralis yang modern dan dinamis, (3) potensi konflik dalam pluralisme struktural dipertahankan pada tingkat yang masih dapat ditoleransi, (4) dalam masyarakat, khususnya yang aktif dalam politik ada budaya politik dan sistem keyakinan yang mendukung ide demokrasi dan lembaga poliarki (John Markoff, 2002). 
Jurnal Pemikiran Sosiologi Volume 1 No. 1, 2012

Heru Nugroho

Demokrasi dan Demokratisasi:

Sebuah Kerangka Konseptual untuk Memahami Dinamika Sosial Politik di Indonesia

Jadi praksis demokrasi yang paling substansial adalah negara wajib melindungi rakyat, utamanya dalam merepresentasikan hak-hak kewargaan mereka, lebih utama lagi dalam menyelenggarakan terciptanya hak-hak dasar hidup yang layak. Untuk itu maka negara berkewajiban mengendalikan dan mengatur gejala kekuasaan yang asosial. Negara juga harus mampu mengorganisasi dan mengintegrasikan kegiatan manusia dan golongan ke arah tercapainya tujuan negara. Jadi secara umum bagi negara yang demokratis kebijakan negara adalah kebijakan dalam rangka mewujudkan kesejahteraan warga. Dukungan dari warga akan diperoleh manakala anggota warga merasa kehendak dan kepentingannya mendapat saluran yang wajar. Agar tidak terjadi penyimpangan demokrasi maka yang diperlukan adalah penegasan perlunya keseimbangan yang kuat di antara elemenelemen negara untuk pencapaian kesejahteraan masyarakat, dimana masyarakat secara efektif terlayani melalui sarana dan perlengkapan pemerintah. Untuk itu maka harus ada penguatan paradigma di kalangan rakyat ke arah "high trust society" yaitu masyarakat yang memiliki kepercayaan dan rasa hormat akan kredibilitas pemerintah yang berkuasa. Dalam masyarakat yang rendah tingkat kepercayaannya kepada pemerintahannya akan sangat sulit membangun dan membangkitkan partisipasi. Kondisi ini tentu saja akan menjadi batu sandungan bagi penguatan iklim demokrasi di negara itu.

Kontrol atas kekuasaan sebuah "state" dalam menjalankan sistem pemerintahannya agar tidak berlaku totaliter dilakukan oleh rakyat. Dengan kontrol ini maka ketertiban bersama, kesejahteraan umum dan hak-hak individu rakyat akan tetap terjaga. Karena itu wewenang negara demokrasi adalah terbatas, yaitu sejauh mandat yang diberikan rakyat melalui pemilu dan sejauh praksis pencapaian kesejahteraan bersama menjadi tujuannya (Muji Sutrisno, 2000). Dengan demikian jelaslah bahwa di satu pihak sistem negara demokratis membutuhkan penataan kelembagaan sebagai mekanisme pembagian kekuasaan demi kesejahteraan masyarakat. Di lain pihak bila mekanisme kelembagaan sudah dibuat dan terus berproses, tidak otomatis bisa dikatakan demokrasi telah berjalan optimal. Demokrasi baru dapat dikatakan berhasil apabila tujuan society mendirikan state telah dicapai. Tujuan yang harus diupayakan terwujudnya adalah adanya kesejahteraan masyarakat, yang secara hukum berarti terjaminnya hak hidup dan martabat masingmasing warga negara di negara tersebut.

\section{B. Demokrasi Liberal Versus Demokrasi Sosial}

Pada lingkup global saat ini terdapat dua tipe demokrasi yang bertarung memperebutkan dominasi politik dan spirit, yaitu demokrasi libertarian dan sosial. Keduanya mengaku strategi tepat untuk menyelenggarakan kebebasan dan keadilan lembaga dan memberikan pemahaman yang berbeda tentang konsep kebebasan dan keadilan dalam kehidupan sosial, ekonomi, budaya dan politik. Konsep demokrasi libertarian dikelompokkan berdasar kenyataan bahwa negara pemerintah meskipun merupakan bagian dari struktur demokratis dalam koridor undang-undang, namun sebagian besar kondisi sosial ekonomi tetap 
Jurnal Pemikiran Sosiologi Volume 1 No. 1, 2012

Heru Nugroho

Demokrasi dan Demokratisasi:

Sebuah Kerangka Konseptual untuk Memahami Dinamika Sosial Politik di Indonesia

dianggap sebagai wilayah pribadi yang lepas dari campur tangan dan struktur politik. Tuntuan atas keseluruhan tanggung-jawab pemerintah untuk membentuk struktur sosial, mengatur perekonomian dan menjalankan kebijakan penyebaran ulang guna melaksanakan nilai dasar kebebasan dan keadilan bagi pihak yang mampu, akan dianggap sebagai sebuah invasi tidak sah oleh negara ke dalam wilayah pribadi kebebasan warga negara. Kebebasan demokratis dan hak-hak warga negara dalam bidang politik, sosial dan ekonomi adalah suatu hal yang tidak boleh dikendalikan oleh pemerintah dan idealnya justru memberikan peluang terjadinya otonomi swasta, kontak yang dilakukan sendiri pihak swasta serta pasar yang mengatur dirinya sendiri (Meyer, 2005).

Pada pelaksanaannya selama dua abad terakhir, demokrasi liberal menyebabkan munculnya perbedaan cukup besar dalam prasyarat sosial, pendidikan dan personal. Di dalam kehidupan sosial ekonomi, hasilnya adalah kesenjangan besar dan sering terus berkembang dalam kesempatan dan pilihan bagi kelas masyarakat berbeda. Sebagian besar masyarakat akan tersisihkan dan kemudian tidak memiliki barang sosial untuk hidup layak. Sebagian besar populasi akan terjerat ketergantungan kebutuhan ekonomi dan sosial serta berdampak kepada tersisihnya dari dinamika kehidupan masyarakat, sosial, dan budaya secara layak. Ketergantungan ekonomi dan kebutuhan sebagian besar anggota masyarakat ini berujung pada hilangnya kesempatan dan peluang mereka untuk menggunakan hak sipilnya secara demokratis. Dari kenyataan ini akan muncul suatu tipe demokrasi defektif yang menyangkal dan mengerosi hak kewarganegaraan berupa hak sipil dan politik. Oleh sebab itu demokrasi libertarian dianggap akan cenderung menjadi sebuah tipe demokrasi elit atau delegatif. Tipe demokrasi ini akan membatasi kesempatan partisipasi demokrasi yang penuh pada sebagian besar anggota masyarakat dan hanya akan memberi kesempatan itu pada sekelompok kecil masyarakat atau hanya pada warga negara tertentu saja (Richard Falk, 1981).

Berdasarkan kenyataan itu, ketika demokrasi liberal membawa kekurangan dan kontradiksi dalam praktek pelaksanaannya pada abad 19 di Eropa, maka setelah pengalaman krisis ekonomi dunia tahun 1920-an dan terutama setelah perang Dunia II di sebagian besar negara Eropa menerapkan praktek demokrasi sosial. Hal ini dilakukan sebagai upaya perbaikan terhadap praktek demokrasi liberal yang banyak akses negatifnya tersebut. Landasan dari konsep demokrasi sosial modern adalah konvensi hak-hak dasar PBB tahun 1966, dokumen ini merupakan bagian yang sah dari hak internasional. Pada dokumen ini diatur dan dilindungi lima hak asasi yang harus dimiliki manusia yaitu hak sipil, politik, sosial, ekonomi, dan budaya (Meyer, 2005).

Gagasan dibalik lima dimensi konsep hak asasi tersebut pada dasarnya adalah jaminan terciptanya peluang bagi setiap individu warga negara untuk memperoleh kebebasan dan kesempatan pengembangan personal serta membuka peluang adanya ruang bagi setiap individu untuk berpartisipasi penuh dalam kehidupan sosialnya. Semua itu haruslah dijamin tanpa memandang status sosial, ekonomi, latar belakang etnis, agama, budaya, dll. Konvensi perlindungan lima hak asasi 
Jurnal Pemikiran Sosiologi Volume 1 No. 1, 2012

Heru Nugroho

Demokrasi dan Demokratisasi:

Sebuah Kerangka Konseptual untuk Memahami Dinamika Sosial Politik di Indonesia

manusia yang merupakan pondasi bagi terwujudnya demokrasi sosial ini diratifikasi oleh 148 negara dengan aneka latar belakang budaya dan tingkat sosial ekonomi.

Suatu negara yang menjalankan konsepsi demokrasi sosial dituntut untuk menawarkan perlindungan sosial pada warganya dari kemungkinan terjadinya pelanggaran hak asasi. Disamping itu, negara juga harus mampu memberikan jaminan pada warganya supaya berkesempatan memperoleh dan menikmati fasilitas pendidikan yang memadai. Warga masyarakat tidak hanya sekedar dimungkinkan memperoleh ketrampilan, tetapi juga diarahkan agar dapat turut ambil bagian dalam dinamika kehidupan kebudayaan yang lebih luas. Tidak kalah pentingnya, bagi negara yang menjalankan konsep demokrasi sosial harus dapat menjaga harkat dan martabat warganya dalam konteks ekonomi dan sosial. Oleh karena itu negara wajib dapat mengelola dan mengendalikan dominasi iklim kapitalis agar tetap berjalan pada koridor yang tidak merugikan warga. Negara juga harus membuka dan memberdayakan ruang publik secara optimal sebagai instrumen warga dalam menyalurkan aspirasinya (Myron Weiner, 1987).

Konsep demokrasi sosial menuntut setiap negara yang mempraktekkannya agar selalu memiliki jaminan sosial atas warganya secara menyeluruh. Jaminan sosial itu harus mampu memberikan perlindungan atas hak-hak dasar yang semestinya dimiliki oleh semua individu sebagai warga negaranya. Negara diwajibkan untuk dapat mempertahankan sebuah penyebaran kesempatan hidup yang adil. Negarapun dituntut harus mampu memberikan jaminan keberhasilan atas pertumbuhan ekonomi serta kohesi sosial dan kestabilan politik. Pada kondisi terdapat ketidakstabilan sosial, politik dan ekonomi negara harus mampu meredam goncangan itu agar tidak berlarut-larut. Negara juga harus dapat memberikan rasa aman bagi warganya dari kondisi ketidakberdayaan akibat dominasi sistem kapitalisme pasar. Disamping itu, untuk pengoptimalan aplikasi konsep demokrasi sosial pada suatu negara, maka negara tersebut harus dapat menyediakan pendapatan minimum untuk individu dan keluarga, juga menawarkan perlindungan efektif terhadap penyakit, kemiskinan di usia tua dan pengangguran. Selain itu juga dituntut untuk menyediakan sejumlah pelayanan sosial seperti pengawasan anak dan perawatan terhadap lanjut usia.

Demokrasi sosial di negara maju ada tiga tipe yaitu negara sosial keuniversalan dalam pola skandinavia, negara sosial konservatif dijalankan pada negara Eropa kontinental dan negara sosial model liberal yang ada di negara Anglo Saxon. Tipe negara sosial ini dapat dibedakan berdasarkan pada tingkat kedalaman dan keseriusan negara tersebut dalam melindungi dan melembagakan hak-hak kewarganegaraan sosial. Sebuah parameter untuk mengetahui keseriusan suatu negara dalam melaksanakan demokrasi sosial dapat dilihat pada ada tidaknya jaminan dalam undang-undang dasar negara itu atas hak kewarganegaraan dalam pelayanan sosialnya. Di negara sosial liberal yang memiliki ketentuan pengentasan kemiskinan namun tidak disertai kepastian hukum yang menjamin kepastian pelaksanaan hal ini pada masyarakat penerimanya, akan gagal memenuhi kriteria 
Jurnal Pemikiran Sosiologi Volume 1 No. 1, 2012

Heru Nugroho

Demokrasi dan Demokratisasi:

Sebuah Kerangka Konseptual untuk Memahami Dinamika Sosial Politik di Indonesia

demokrasi sosial. Sementara dua tipe yang lain telah dengan jelas melembagakan jaminan atas pelaksanaan hak-hak kewarganegaraan sosialnya.

Namun demikian keberhasilan pelaksanaan demokrasi sosial pada suatu negara tidak sematamata hanya ditangan pemerintahannya. Warga negara juga memiliki kewajiban tertentu yang dapat melengkapi hak-hak dasar mereka. Warga negara tidak semata-mata menunggu untuk menerima hak kewarganegaraan sosialnya, namun juga memiliki peran secara aktif dalam memikul tanggung jawab atas hidup mereka sendiri. Setiap warganegara berkewajiban untuk meminta bantuan hanya ketika usahanya sendiri yang telah dikelola secara serius untuk memperoleh penghasilan sendiri tidak berhasil. Hal ini adalah sebuah persyaratan untuk pemeliharaan seluruh sistem keamanan sosial (Meyer, 2004).

Di dalam praktek demokrasi sosial, setiap pemerintahan dituntut memiliki komitmen untuk menjamin adanya kesetaraan kesempatan dan keadilan bagi setiap warganya. Kesetaraan dan keadilan itu tidak hanya dalam bidang politik semata, tetapi juga dalam bidang sosial dan ekonomi. Negara harus memberi jaminan atas ketersediaan kesempatan dasar dalam kehidupan warga. Agar dapat melakukan itu semua, negara harus memiliki jaminan berupa kepastian hukum dalam bentuk undang-undang, sehingga negara benar-benar dapat memberikan jaminan kesejahtaraan berbasis hak bagi warganya. Hal ini merupakan tanggung jawab politik suatu negara demokratis yang dapat mengakomodasi kebutuhan hajat hidup warganya.

\section{Akselerasi Proses Demokratisasi}

Agar terjadi percepatan proses demokratisasi di suatu negara membutuhkan suatu kondisi yang kondusif. Ada sejumlah hal yang dapat menjadi pra kondisi bagi terciptanya akselerasi demokratisasi suatu negara. Ada yang beranggapan bahwa faktor ekonomi adalah merupakan prasyarat utama bagi berlangsungnya proses demokratisasi di suatu negara. Masyarakat industri modern yang diasumsikan memiliki tingkat kemampuan ekonomi yang tinggi akan lebih mudah menciptakan suatu negara yang demokratis. Asumsi itu didukung oleh pernyataan seorang ahli politik yang bernama Seymour M. Lipset yang menyatakan bahwa semakin kaya suatu bangsa maka akan semakin besar peluang negara tersebut untuk melangsungkan demokrasi (Sorensen, 1993). Pendapat Lipset ini didukung kenyataan bahwa modernisasi dan kesejahteraan akan selalu disertai dengan sejumlah faktor yang kondusif bagi demokrasi yaitu meningkatnya tingkat melek huruf dan tingkat pendidikan, urbanisasi dan pembangunan media massa. Kesejahteraan masyarakat yang tinggi juga akan menyediakan sumberdaya yang dibutuhkan untuk meredakan ketegangan yang ditimbulkan oleh konflik politik. Pernyataan Lipset itu juga didukung oleh hasil penelitian yang dilakukan pengamat politik yang lain yaitu Robert Dahl, yang menyebutkan bahwa semakin tinggi tingkat sosial ekonomi suatu negara akan semakin mungkin bagi masyarakat untuk menjadi demokratis.

Namun pendapat dan argumen yang dilontarkan Lipset dan Robert Dahl itu terbantahkan oleh kenyatan empiris yang terjadi di sejumlah negara. Di 
Jurnal Pemikiran Sosiologi Volume 1 No. 1, 2012

Heru Nugroho

Demokrasi dan Demokratisasi:

Sebuah Kerangka Konseptual untuk Memahami Dinamika Sosial Politik di Indonesia

Argentina pernah terjadi praktek politik otoritarianisme selama bertahun-tahun padahal tingkat pendapatan perkapita rakyatnya relatif tinggi, bangsa ini pada saat itu cukup makmur secara ekonomi. Demikian pula kasus yang sama terjadi di Taiwan dan Korea Selatan. Bahkan pada kasus yang terjadi di Korea Selatan pembangunan ekonomi yang cepat disertai dengan distribusi pendapatan yang cukup merata, namun hal itu tidak disertai dengan korelasi yang paralel dengan berlangsungnya praktek akselerasi demokratisasi. Jadi menurut pengamatan beberapa ilmuwan politik bahwasannya kemakmuran suatu masyarakat, kesejahteraan ekonomi suatu bangsa tidak dapat menjadi jaminan absolut akan terjadinya pelaksanaan konsep demokrasi di negara-negara ekonomi maju itu.

Pendapat yang lain mengatakan bahwa akselerasi demokratisasi di suatu negara disebabkan oleh prakondisi yang berupa budaya politik dari suatu bangsa. Menurut asumsi ini lebih lanjut dijelaskan bahwasanya sistem nilai dan keyakinan akan menjelaskan konteks dan makna dari tindakan politik. Namun tesis ini memunculkan suatu pertanyaan baru; apabila budaya politik berhubungan dengan sistem budaya yang lebih luas dalam masyarakat, mungkinkah diidentifikasi akan menjadi nilai dan keyakinan budaya yang kondusif bagi demokrasi. Salah satu jawaban yang muncul dari pertanyaan itu adalah apa yang terjadi pada gerakan Protestantisme. Ideologi Protestantisme mendukung terjadinya praktek demokrasi di suatu negara, namun bagi ideologi yang lain yaitu Katolisisme dalam banyak kasus terutama di Amerika Latin justru menghambat demokrasi dalam pengertian yang lebih luas, sejumlah budaya lebih menekankan pada hirarki, otoritas dan intoleransi dibandingkan budaya yang lain. Jadi dapat dikatakan bahwa budaya-budaya itu kurang kondusif bagi pelaksanaan demokratisasi di suatu negara, termasuk dalam hal ini adalah Islam dan Konfusionisme (Sorensen, 1993).

Namun demikian memang diakui oleh banyak ahli bahwa sulit untuk melihat suatu hubungan yang sistematis dan pasti antara pola budaya tertentu dan privalensi demokrasi, ada hal-hal yang bersifat relatif. Sistem budaya merupakan subyek perubahan yang bersifat dinamis. Hal ini nampak pada ideologi Katolisisme, pada satu kurun waktu tertentu dalam perjalanan sejarah, ideologi ini menghambat demokrasi di Amerika Latin, tetapi pada sisi lain gereja Katolik juga memainkan peranan penting dan aktif dalam oposisinya terhadap pemerintah otoriter di tahun 1980-an. Demikian juga dengan ideologi Islam, di beberapa negara di Timur Tengah ideologi ini mungkin menghambat proses demokratisasi, namun di Indonesia pada masa reformasi ini, kelompokkelompok partai yang berspesifikasi pada ideologi Islam sangat mendukung pada terjadinya proses demokratisasi yang sedang berlangsung dengan marak di Indonesia.

Prakondisi lain yang dianggap dapat menjadi pemicu dan pemacu bagi tegaknya iklim demokrasi di suatu negara adalah struktur sosial masyarakat. Prakondisi ini berupa faktor-faktor internal yang berupa sistem pelapisan sosial yang ada di masyarakat. Diartikan bahwa kelas sosial tertentu akan memberikan dukungan yang signifikan bagi terjadinya proses demokratisasi namun kelas sosial 
Jurnal Pemikiran Sosiologi Volume 1 No. 1, 2012

Heru Nugroho

Demokrasi dan Demokratisasi:

Sebuah Kerangka Konseptual untuk Memahami Dinamika Sosial Politik di Indonesia

yang lain justru menentangnya. Namun demikian lagi-lagi kita dihadapkan pada adanya unsur relatifitas di dalamnya. Pada struktur kelas yang dianggap mendukung proses demokratisasi itu pada situasi dan kondisi lain yang berbeda ternyata adakalanya justru menjadi faktor penghambat terjadinya proses demokratisasi, demikian pula sebaliknya. Kelas yang selama ini diposisikan sebagai faktor penghambat proses demokratisasi pada situasi dan kondisi yang berbeda mereka justru memberikan dukungan yang besar bagi terciptanya iklim demokrasi. Hal ini terlihat pada kajian historis yang dilakukan oleh seorang pengamat politik Barrington Moore dalam bukunya Sorensen, Moore menyimpulkan bahwa kaum borjuis dalam kadar tertentu bekerja untuk proses demokratisasi suatu bangsa, namun thesis Moore ini dibantah oleh pengamat politik yang lain yaitu Goran Thurbon, menurut pendapat Thurbon, di banyak negara, demokratisasi muncul sebagai bentuk perjuangan masyarakat melawan dominasi dan hegemoni kaum borjuis.

Faktor lain yang dapat dijadikan modal bagi berlangsungnya iklim demokratis suatu masyarakat adalah faktor eksternal. Kondisi ekonomi politik, ideologi dan elemen lain dalam skala global akan mempengaruhi praktek demokrasi di suatu negara. Menurut beberapa kalangan faktor eksternal itu akan sangat mempengaruhi tingkat akselerasi kesadaran masyarakat khususnya di negara-negara berkembang, akan pentingnya penerapan ideologi demokrasi dalam sistem politiknya. Pengamat modernisasi berpendapat bahwa faktor-faktor eksternal itu akan mempengaruhi bagi upaya pengembangan dan penguatan penerapan doktrin demokrasi di negara-negara dunia ketiga. Namun pendapat inipun disangkal kebenarannya, teoritisi dependensi menarik kesimpulan yang bertolak belakang. Ketimpangan dan distorsi ekonomi yang terjadi di masyarakat dunia ketiga disebabkan oleh karena adanya ketergantungan pada sistem ekonomi dunia. Hal ini membuat praktek demokratisasi di negara dunia ketiga sulit diwujudkan.

Berdasarkan paparan diatas dapat disimpulkan bahwasanya sulit sekali untuk merumuskan suatu model yang absolut untuk dapat dijadikan rujukan bagi terjadinya akselerasi untuk pelaksanaan demokrasi di suatu negara. Prakondisi yang nampaknya kondusif bagi implementasi ideologi demokrasi di suatu negara ternyata di dalamnya juga terdapat hal-hal yang kontra produktif bagi berlakunya iklim demokrasi. Namun demikian pengakuan terhadap pentingnya prakondisi di atas bagi terlaksananya suatu proses demokratisasi di suatu negara bukan suatu hal yang percuma. Setidaknya pemahaman akan prakondisi di atas seperti dijadikan sebagai bahan pertimbangan untuk memperjuangkan berlangsungnya suasana sistem politik yang demokratis di suatu negara. Namun demikian para aktor politik juga tetap harus kritis untuk memperhatikan prakondisi lain yang terjadi sebelumnya. Pelaksanaan demokrasi di suatu negara tidak dapat lepas dari struktur dan prakondisi yang merupakan hasil pembangunan dan aktifitas elit politik di masa lampau. Oleh karena itu kita harus melihat bahwasanya terlaksananya atau tidak terlaksananya proses demokratisasi di suatu negara dipengaruhi dan ada kaitannya dengan prakondisi ekonomi, sosial, budaya dan lain-lain, 
Jurnal Pemikiran Sosiologi Volume 1 No. 1, 2012

Heru Nugroho

Demokrasi dan Demokratisasi:

Sebuah Kerangka Konseptual untuk Memahami Dinamika Sosial Politik di Indonesia

yang terbentuk pada periode sebelumnya dan tentunya itu harus menjadi bahan pertimbangan dan rujukan para elit politik di suatu negara pada saat ini.

\section{Praktik Demokrasi di Indonesia}

Tahun 1998 adalah merupakan babak baru dalam dinamika sistem politik di Indonesia, pada tahun itu dimulailah tradisi demokrasi dalam semua proses politik di negara ini. Setelah hampir 32 tahun terdominasi dan terhegemoni sistem politik yang sangat militeristik dan bersifat sentralistik, maka era '98 melepaskan proses politik Indonesia dari jeratan dan pasungan intervensi politik negara yang sangat dominatif. Angin perubahan bertiup kencang menyapu debu-debu praktek otoritarianisme di masa lampau diganti dengan iklim yang segar bagi berseminya tunas-tunas demokrasi di segala bidang kehidupan.

Reformasi politik yang telah berlangsung selama lebih dari 10 tahun memberikan manfaat yang besar bagi dinamika sistem politik di Indonesia. Fenomena kebebasan politik ini diharapkan dapat menjadi sarana bagi terbangunnya suatu tata pemerintahan yang bersih, adil dan berwibawa. Dengan terjadinya proses demokratisasi di Indonesia tentunya diharapkan akan terbentuk suatu negara demokratis yang memiliki kredibilitas tinggi dan terwujudnya suatu masyarakat sipil yang sejahtera. Banyak keuntungan dan kemanfaatan yang diraih sebagai dampak terjadinya gelombang perubahan di Indonesia. Keberhasilan dari arus reformasi ini diantaranya adalah terbentuknya puluhan partai yang digalang oleh aneka kelompok masyarakat yang memiliki latar belakang ideologi, aspirasi dan tradisi politik yang bervariasi. Demikian pula terjadi liberalisasi media massa yang sangat luas, media sangat leluasa dalam mencari dan menyebarkan informasi pada publik. Rakyat tidak dihalanghalangi ketika hendak menyampaikan aspirasinya. Keterbukaan bagi seluruh elemen masyarakat didalam melontarkan kritik dan saran kepada penguasa di ruang publik.

Hal positif lain yang dicapai dengan adanya reformasi di segala bidang di Indonesia adalah partisipasi sipil meningkat, masyarakat politik tumbuh subur, berbagai upaya pemulihan dan pembangunan ekonomi diselenggarakan, desentralisasi dan otonomi daerah diterapkan, penegakan hukum dan pemberantasan korupsi dilakukan dengan sungguh-sungguh dan transparan, kampanye perlindungan HAM semakin marak, reformasi sektor pertahanan dan keamanan menjadi agenda yang diprioritaskan. Tuntutan bagi suatu negara yang demokratis juga berhasil diwujudkan, yaitu terselenggaranya pemilihan umum yang dilandasi semangat penegakkan prinsip keadilan dan kejujuran.

Musim semi demokratisasi di Indonesia terlihat juga pada terjadinya desakralisasi lembaga kepresidenan. Pada masa orde baru yang bercorak absolut, presiden adalah penguasa tunggal dan tidak dapat tersentuh oleh hukum. Tetapi ketika reformasi bergulir presiden dapat ditumbangkan dari tampuk kekuasaannya melalui mekanisme konstitusional oleh rakyat. Ini adalah suatu fenomena kemajuan dalam sistem politik di Indonesia. Hal lain yang dapat menjadi parameter keberhasilan proses demokratisasi di Indonesia 
Jurnal Pemikiran Sosiologi Volume 1 No. 1, 2012

Heru Nugroho

Demokrasi dan Demokratisasi:

Sebuah Kerangka Konseptual untuk Memahami Dinamika Sosial Politik di Indonesia

adalah terselenggaranya tiga kali pemilu yang relatif lancar yaitu pemilu tahun 1999, 2004, dan 2009. Bagi sebuah negara demokrasi, pelaksanaan pemilu adalah merupakan momentum dalam mempertegas arah konsolidasi demokrasi dan penguatan kelembagaan politik. Dengan terlaksananya pemilu di Indonesia itu, maka transisi demokrasi di Indonesia dapat berjalan sesuai rencana dan mampu mendorong Indonesia sebagai negara "South East Asia's only fully functioning Democracy". Proses demokratisasi di Indonesia akan menjamin semakin kokohnya sistem demokrasi sosial yang berlanjut (suistainable constitutional democracy), dimana hal ini sangat dibutuhkan guna menempatkannya sebagai instrumen efektif yang bekerja bagi terwujudnya kesejahteraan masyarakat.

Namun demikian kita juga tidak boleh menutup mata, bahwa sebagai bangsa yang baru saja menjalankan roda demokrasi dalam praktek penyelenggaraan negara, masih banyak ditemui kelemahan dan kekurangan. Kelemahan itu diantaranya adalah sektor kehidupan masyarakat baik dalam bidang ekonomi, pendididkan, kesehatan, pengelolaan lingkungan hidup dll, masih jauh dari apa yang diangankan masyarakat. Pemaksaan kehendak, kekerasan politik, korupsi dan keculasan yang dilakukan aparat legislatif, eksekutif dan yudikatif bukannya semakin menyusut namun menunjukkan eskalasi yang meningkat, munculnya puluhan partai baru pada pemilu 2009 tidak memberikan rasa optimisme pada masyarakat, namun justru menciptakan rasa pesimis, skeptis bahkan sikap sinis. Anggapan yang berkembang pada masyarakat, partai politik hanya akan dijadikan kedok dan kendaraan bagi petualang politik dalam meraih dan mewujudkan hasrat pribadi dan ambisi yang jauh dari upaya menyejahterakan rakyat.

Boleh dikatakan bahwa proses demokratisasi yang terjadi di Indonesia baru sebatas meningkatkan kebebasan politik dan penghargaan atas hak asasi manusia, tetapi belum membawa kepada pembangunan ekonomi yang cepat dan memberdayakan ekonomi rakyat yang bisa mengentaskan dari jerat kemiskinan. Demokratisasi di Indonesia masih direcoki dengan tindakantindakan anarkis dan menyulut kekacauan sosial. Hal ini disebabkan karena iklim demokratis yang seharusnya mengedepankan tatanan dan ketertiban serta moralitas dalam berpolitik, namun dalam prakteknya yang terjadi adalah merebaknya fenomena dimana pemimpin dan masyarakat dapat melakukan apapun sesuai dengan yang mereka inginkan dan sistem hukum (aturan) dilecehkan serta tidak dihormati.

Meskipun proses pemilu tahun 2009 dapat terselenggara, namun ada hal yang cukup signifikan sebagai bagian pembelajaran bagi pelaksanaan demorasi di Indonesia. Pemilu 2009 di Indonesia meskipun secara umum berlangsung kondusif, namun banyak terjadi kelemahan dan kesemrawutan. Hal ini terjadi karena Komisi Pemilihan Umum (KPU) sebagai penyelenggara tidak dapat melaksanakan tugasnya secara profesional. Hal ini ditandai dengan Daftar Pemilih Tetap (DPT) yang kacau, surat suara yang salah alamat, penghitungan suara yang melebihi tenggat waktu yang ditetapkan (tidak konsisten dan berubah-ubah) instrumen teknologi informasi (IT) yang dipergunakan KPU untuk penghitungan suara 
Jurnal Pemikiran Sosiologi Volume 1 No. 1, 2012

Heru Nugroho

Demokrasi dan Demokratisasi:

Sebuah Kerangka Konseptual untuk Memahami Dinamika Sosial Politik di Indonesia

secara cepat namun hasilnya tidak seperti yang diharapkan, padahal piranti itu dibeli dengan dana rakyat yang besarnya milyaran rupiah, dugaan adanya kecurangan pemilu berupa praktek penggelembungan suara pada salah satu parpol dll.

Kelemahan-kelemahan ini menunjukkan kacaunya sistem managemen dan tidak kompetennya personel KPU yang memperihatinkan. Carut marut kinerja KPU ini akan dapat mengakibatkan terjadinya cacat moral dan politik yang sangat mencederai berlangsungnya proses demokratisasi di Indonesia.

Disamping lemahnya tata kerja KPU dalam penyelenggaraan pemilu 2009, hal yang tidak kalah pentingnya bagi terjadinya cacat moral dan politik di Indonesia adalah maraknya praktek jual beli suara (money politics). Hal ini menampakkan bahwa saat ini para elit politik di Indonesia masih memandang bahwa menjadi anggota legislatif adalah bukan jabatan amanah untuk memperjuangkan aspirasi rakyat, tetapi merupakan kekuatan sebagai legitimator dan pengakses sumber-sumber kuasa (tidak hanya politis) tetapi juga sosial, ekonomi dan sebagainya. Sehingga jangan heran kalau rakyat menjadi skeptis dan apatis terhadap hasil pemilu 2009. Rakyat menjadi malas untuk berpartisipasi dalam kegiatan lima tahunan ini, hal ini terlihat pada tingginya angka pemilih yang tidak menggunakan haknya (golput). Hal ini tentu tidak boleh dibiarkan, kedepan harus ada penyempurnaan baik pada institusi pe- nyelenggara KPU maupun kualitas intelektual dan moral dari para calon legislatif.

Akselerasi demokratisasi di Indonesia masih panjang dan berliku, masih dibutuhkan upaya-upaya yang konkret di dalam mengimplementasikan konsep demokrasi ini. Adapun upaya-upaya itu diantaranya adalah:

Pertama, pemahaman nilai-nilai demokrasi secara individual. Nilai-nilai yang mendorong terwujudnya kompetisi, partisipasi dan kebebasan perlu diinternalisasi pada tingkat individual sehingga terwujud tata tertib sosial. Perilaku kompetisi tidak diartikan sebagai perilaku saling memaki, menghujat dan menjatuhkan, partisipasi tidak dimaknai sebagai kemauan yang bebas tanpa batas. Tiga nilai tersebut harus menjelma dalam perilaku sosial masyarakat Indonesia dan diharapkan akan membangun ketertiban sosial.

Kedua, pembentukan masyarakat sipil dan kelembagaan sosial. Demokrasi mensyaratkan adanya masyarakat sipil yang mandiri (Chandoke, 1999) yaitu masyarakat yang sadar akan terbentuknya ketertiban sosial tanpa melalui caracara kekerasan. Segala persoalan yang timbul dan dihadapi oleh masyarakat harus diselesaikan melalui dialog dan negosiasi dalam rangka mencari solusi tanpa campur tangan kekuasaan negara melalui tangan-tangan aparatnya. Apabila hal ini dapat terwujud di Indonesia maka masyarakat yang memiliki tipe ini akan menjadi kekuatan pengontrol bagi kebijakan publik dan pembentukan hukum karena ia akan mengontrol kinerja lembaga pemerintah, legislatif dan yudikatif dengan sikap kritisnya. Agar tercipta masyarakat yang tertib dan kritis itu maka diperlukan adanya penguatan kapasitas kelembagaan masyarakat yang dapat dijadikan sebagai sarana untuk perjuangan masyarakat.

Ketiga, perbaikan kinerja parlemen, yaitu peningkatan kapasitas lembaga legislatif sebagai 
Jurnal Pemikiran Sosiologi Volume 1 No. 1, 2012

Heru Nugroho

Demokrasi dan Demokratisasi:

Sebuah Kerangka Konseptual untuk Memahami Dinamika Sosial Politik di Indonesia

institusi politik yang mewakili kepentingan masyarakat baik di tingkat lokal, regional dan nasional dirasa sangat mutlak diperlukan. Mereka yang telah terpilih dan duduk di DPR baik pusat, tingkat I dan II seyogyanya tidak lagi sekedar menyuarakan kepentingan kelompoknya tetapi harus menyatu dan menyuarakan kepentingan masyarakat secara luas. Ini semua untuk menghindari kesan bahwa demokrasi perwakilan hanya memberi kesempatan partisipasi lima tahun sekali kepada masyarakat ketika negara sedang menyelenggarakan pemilu. Setelah terbentuk wakilwakilnya di DPR dan setelah presiden terpilih membentuk kabinet, mereka kaum eksekutif dan legislatif bekerja sendiri untuk mengeluarkan berbagai kebijakan dan hukum dengan meninggalkan masyarakat di belakangnya. Untuk meningkatkan partisipasi masyarakat dalam pengambilan kebijakan publik dan pembuatan perundang-undangan tidak ada cara lain kecuali para anggota DPR harus aktif mendatangi masyarakat. Jangan mengulang kegagalan DPR masa lalu yang hanya menunggu masukan dari masyarakat dan kemudian menampung aspirasi itu. Situasi ini akan menghasilkan ketidakpercayaan masyarakat pada lembaga yang terhormat ini.

Keempat, peningkatan kepekaan pemerintah, hal ini terjadi bila secara umum pemerintah bisa menegakkan keadilan dan sekaligus mensejahterakan kehidupan segenap lapisan kehidupan segenap lapisan masyarakat yang ada di negara Indonesia. Indikator yang paling komplit adanya pemerintahan yang memiliki kepekaan adalah pemerintahan yang secara aktif mengambil peran dalam pembentukan undang-undang tanpa harus menunggu masalah muncul ke permukaan. Sebelum mengusulkan perundangan, melalui kebijakan departemen yang terkait pemerintah harus bersikap terbuka dan sekaligus aktif mencari masukan, kritik dan saran dari masyarakat. Ini merupakan langkah pemerintah dalam mendorong partisipasi dalam pembuatan perundangan dan kebijakan publik. Sebab semakin tinggi tingkat partisipasi masyarakat dalam pembuatan kebijakan dan perundangan maka akan semakin absah pemerintahan itu di mata rakyatnya.

Upaya penyempurnaan proses demokratisasi di Indonesia adalah suatu hal yang masih harus dilakukan. Kalau tidak ada perubahan maka apatisme publik akan semakin menguat, tingkat partisipasi politik semakin melemah dan dampaknya tidak mustahil akan terjadi "negara yang gagal" (the failled state) tentu hal ini adalah suatu hal yang tidak kita inginkan dan sekuat tenaga harus dihindari. Semua pihak harus arif dalam merespon dinamika yang terjadi. Aparat penyelenggara negara baik legislatif, eksekutif maupun yudikatif harus berani melakukan langkah koreksi untuk penyempurnaan secara signifikan. Hanya dengan cara inilah maka frozen democracies dapat dicegah, the failled state dapat dihindari dan bangsa ini dapat lolos dari ujian demokrasi.

\section{Kesimpulan}

Demokrasi adalah konsep politik yang menjadi pilihan sistem politik di berbagai negara dunia ketiga pada dua dasawarsa terakhir. Ambruknya ideologi komunisme Uni Soviet di tahun 1989, semakin menambah popularitas demokrasi sebagai 
Jurnal Pemikiran Sosiologi Volume 1 No. 1, 2012

Heru Nugroho

Demokrasi dan Demokratisasi:

Sebuah Kerangka Konseptual untuk Memahami Dinamika Sosial Politik di Indonesia

ideologi politik. Konsep demokrasi dianggap mampu dan nyata untuk mengatasi masalah sosial politik yang dihadapi berbagai negara.

Agar akselerasi praktek demokratisasi dapat ditingkatkan, maka perlu upaya-upaya konkrit yang harus dilakukan, diantaranya adalah penanaman atas pemahaman nilai-nilai demokrasi secara individual ditingkatkan, pembentukan masyarakat sipil dan kelembagaan sosial, perbaikan kinerja parlemen dan peningkatan kepekaan pemerintah.

Bangsa Indonesia yang masih dalam taraf belajar berdemokrasi harus selalu belajar dan melakukan pembenahan di segala bidang. Kelemahan yang terjadi selama satu dekade proses reformasi digulirkan sebaiknya terus dikoreksi dan diperbaiki. Dengan cara ini maka praktek demokrasi untuk kesejahteraan rakyat dapat direalisasi dan kegagalan demokrasi dapat dihindari.

\section{Daftar Pustaka}

Berger, Peter. L and Richard Neuhauss.1977.To Empower People, the Role of Mediating Structure in Public Policy.Washington: American Enterprise Institute for Public Policy Research.

Chandoake, Neera, 1995. State and Civil Society: Exploration in Political Theory. London: Sage Publication

Falk, Richard, 1981, Human Right and State Sovereignty, New York: Holmes and Meier.

Held, David. 1987. Models of Democracy. Cambridge: Polity Press.

Lechman, David, 1989, Democracy and Development in Latin America, Cambridge: Polity Press.

Mangun Wijaya, 1994. Dalam Sidney Hook, Sosok Filsuf Humanisme Demokrasi Dalam Tradisi Pragmatisme. Jakarta: Yayasan Obor Indonesia.
Macpherson. C. B, 1997. The Life and Times of Liberal Democracy. Oxford: Oxford University Press. Markoff, John, 2002. Gelombang Demokrasi Dunia (terjemahan). Yogyakarta: Pustaka Pelajar.

Meyer. T., 2005. Demokrasi Sosial dan Libertarian. Jakarta: Friederich Ebert Stiftung. 2004. Politik Identitas. Jakarta: Friederich Ebert Stiftung.

Sutrisno, Muji, 2000. Demokrasi Semudah Ucapankah? Yogyakarta: Penerbit Kanisius

Sorensen George, 1993. Democracy and Democratization,Process and Prospect in a Changing World. Oxford: Westview Press Inc.

Weiner, Myron and Samuel P. Huntington. 1981. Understanding Political Development. Boston: Little Brown. 